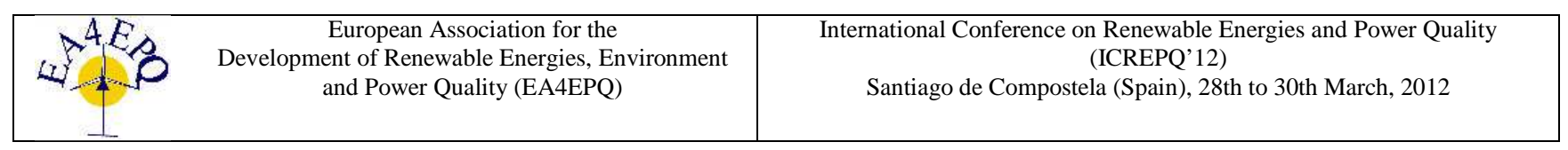

\title{
Modelling and Simulation of a Unified Power System Incorporating Large Scale Wind Farms via Open Source Code Package
}

\author{
Alwadie, $\mathrm{A}^{1}$. and A. M. Abdel-Hamid ${ }^{2}$ \\ ${ }^{1}$ Vice Dean of the Faculty of Engineering, Najran University \\ Najran (Saudi Arabia) \\ Phone number:+966507776986, e-mail: alwadie@hotmail.com, abdel_hamid_mohamed@yahoo.com \\ ${ }^{2}$ Guest Professor of Control of Electrical Power and Machines at the same Department
}

\begin{abstract}
This paper presents a serious trial to formulate a model for the whole Egyptian power system network which may be appropriate for academic as well as field research purposes. The model is based on the latest published data taken from the website and annual reports of the Egyptian Ministry of Electricity and Energy (EMEE) in addition to many other resources. This network provides more than 110 billion MWh and is growing steadily with a rate within 7 and 8 percent every year. It is an ideal exemplar for a very hybrid large scale system since it includes all the possible power system technologies. The Egyptian power stations include hydraulic, steam, gas, solar as well as wind farm plants. The next significant part of this paper is to simulate the presented model with one of the most recent computer packages. PSAT has been selected for such simulation since it is a free and open source package that suits complicated and large scale systems with minimum effort. Even if we take only those significant portions of the Egyptian grid, we'll get 731 states ( 57 buses and 46 synchronous machines in addition to the induction generators of the wind farm) to be simulated and monitored. PSAT as an open source code allows the designer to change the package kernel to lay down such sophisticated model. Other packages are too expensive if one demands versions able to simulate more than specific nodes other the number of nodes which are distributed with the commercial versions. Even so, these packages have prices ranging from $\$ 8000$ (PSCAD) to $\$ 50000$ (EDSA). On the other side PSAT is free and can be broadening by professional users to deal with any power system topology. Moreover, it has been found that PSAT application reduces a lot of time in setting up the power system topology and in preparing several additional files for the same case study if it is dealt with other packages.
\end{abstract}

\section{Key words}

Egyptian Ministry of Electricity and Energy (EMEE), Power system modelling and simulation, Egyptian Electricity Holding company (EEHC), Unified Power System (UPS), Power System Simulation Toolbox (SimPower), Power System Analysis Toolbox (PSAT).

\section{Introduction}

The Egyptian Electricity Holding Company (EEHC) has been reported a constant increase of demand on electric power. The peak load has been increased from $3306 \mathrm{MW}$ in $1980 / 1981$ to $17300 \mathrm{MW}$ in 2005/2006[Fig.1]. This has been countered with an increase of the generated power from 20 billion MWh to about 110 billion MWh in the same period [1-3]. Different projects of power stations, substations, and transmission lines besides upgrading the existing projects have been carried out. Moreover, other projects like the exchange of energy with neighbouring countries through electrical interconnection have been performed.

The electricity network in Egypt has developed into a complex interconnected system referred to as the Unified Power System (UPS) serving all major load centres in the country. In its effort to meet the electrical requirements of areas not being served through the UPS, the Government has constructed many medium and small size gas turbine and diesel generating plants in most of the isolated areas. The UPS includes 30 power stations which incorporate hydraulic, steam, gas, solar as well as wind farm plants.

Unfortunately, a complete model for such a power system which includes about 186 synchronous machines in addition to hundreds of power transformers, buses, and thousands kilometres of transmission lines is not available until now. The purpose of this paper is to provide such a model which may be very helpful for academic as well as field research purposes. In order to achieve this, different resources has been checked. Beside the last three reports of EEHC, an enormous effort has been spent to find exact data for specific power stations, generator loads, power factors, as well as data for transformers and transmission lines.

Peak Load Curve 2002/2003-2003l2004 


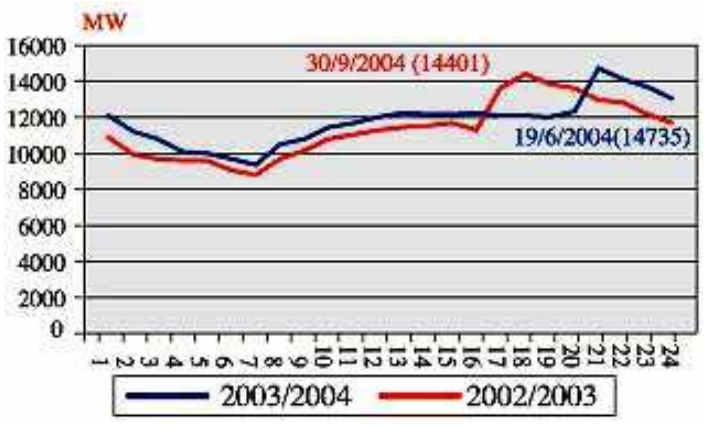

Peak Load Curve 2003/2004-2004/2005

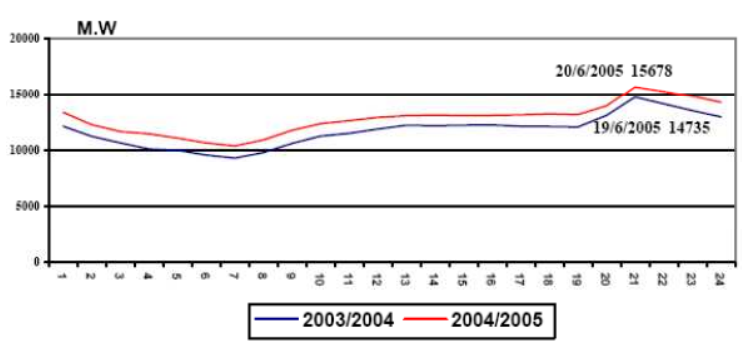

Peak Load Curve 2004/2005-2005l2006

(The available report is only available in Arabic)

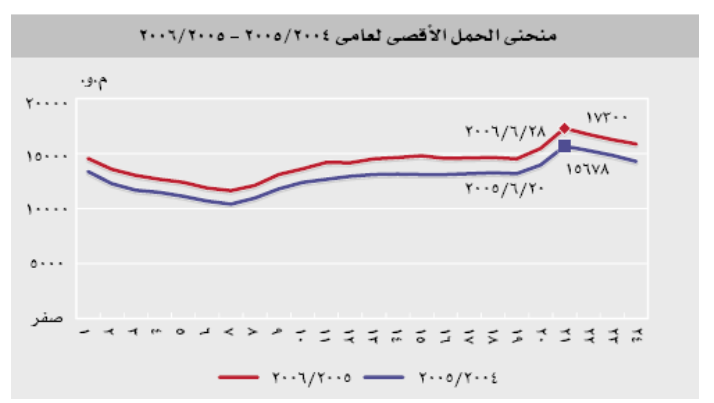

Figure 1: Yearly peak load development in the last 5 years (Courtesy of the Egyptian Electricity Holding Company" EEHC" annual reports)

The EEHC reports just focus on statistical numbers that only valid for medial purposes. Accordingly, this papers covers the obvious lake of the useful technical information in these reports. The next significant part of this paper is to simulate the presented model with one of the most recent computer packages. PSAT has been selected for such simulation since it is a free and open source package that suits complicated and large scale systems with minimum effort. Even if we take only those significant portions of the Egyptian grid, we'll get 731 states (46 buses and 34 synchronous machines in addition to the induction generators of the wind farm) to be simulated and monitored. PSAT as an open source code allows the designer to change the package kernel to lay down such sophisticated model. Other packages are too expensive if one demands versions able to simulate more than specific nodes other the number of nodes which are distributed with the commercial versions. Even so, these packages have prices ranging from $\$ 8000$ (PSCAD) to $\$ 50000$ (EDSA). On the other side PSAT is free and can be broadening by professional users to deal with any power system topology. Moreover, it has been found that PSAT application reduces a lot of time in setting up the power system topology and in preparing several additional files for the same case study if it is dealt with other packages.

\section{The Egyptian UPS Model}

This paper tries to formulate a model for the Egyptian unified power system which may be appropriate for academic as well as field research purposes. The planed strategy to get all the required technical data for such a whole system was divided into these basic topics:

(1) The starting point in this long way toward achieving this goal was the electrical map of Egypt [4]. Figure 2 illustrates such map which is taken from the official web site of the ministry of electricity and energy www.moee.gov.eg. The map is somehow modified by the author to give number codes for the power stations instead of the indicated Arabic names. On this map, the location of every power plant is referred with a link. Following the link associated with any power plant, one gets some important updated information about this specific plant. Out of this information, only useful technical data are collected for the whole 30 stations in Table 2. This table depicts the principal lay out of these plants and summarizes the number and type of the generating units in addition to the generated power for each. However, from this map one can also get the following data:

I. The Egyptian UPS constitutes about 30 Power plants serving the overall load centres.

II. The transmission line (T.L.) may be $500,400,220$, or $132 \mathrm{kV}$ depending on the indicated colour on the map.

III. The Length of a T.L. between two power plants is taken approximately as the official distance between the two cities where these two plants exist.

IV. The transformer parameters and transformation ratios are taken according to the T.L. capacity and voltages.

V. Generator power is calculated as the result of dividing the overall installed capacity of a power plant by the number of generators in this plant. Otherwise, it can be directly taken 
from the available generation data from the EEHC reports (Table 2). Identical data has been obtained.

(2) Synchronous machine data, such as: $r_{a}, x_{a}, x_{d}, x_{d}^{\prime}, x_{d}{ }^{\prime}, x_{q}, x_{q}^{\prime}, x_{q}, x_{l}, T^{\prime}$ do ... etc, are taken from the standard tables according to the machine type and rating. Those tables may be found at any of the power system references or the IEEE publications [5, 6].

(3) The load at different buses is taken from many references, for example some of the loads of significant stations are taken from reference [7]. In this reference only these data are given in table 1:

Table 1: Loads for some stations taken from Ref.7

\begin{tabular}{|l|l|}
\hline \multicolumn{1}{|c|}{ Station } & Bus Load (MW and MVAR) \\
\hline High Dam & $364.7+\mathrm{J} 208.8$ \\
\hline Naga-Hammady & $799.3+\mathrm{j} 481.7$ \\
\hline Assiut & $232.2+\mathrm{j} 114.4$ \\
\hline Samalut & $167.9+\mathrm{j} 147.7$ \\
\hline Kuraimat & $173.2+\mathrm{j} 97.9$ \\
\hline CAIRO 500 & $392.4+\mathrm{j} 650.1$ \\
\hline
\end{tabular}

The rest of loads is either taken from other resources or assumed relative to the plant installed capacity if no data is available.

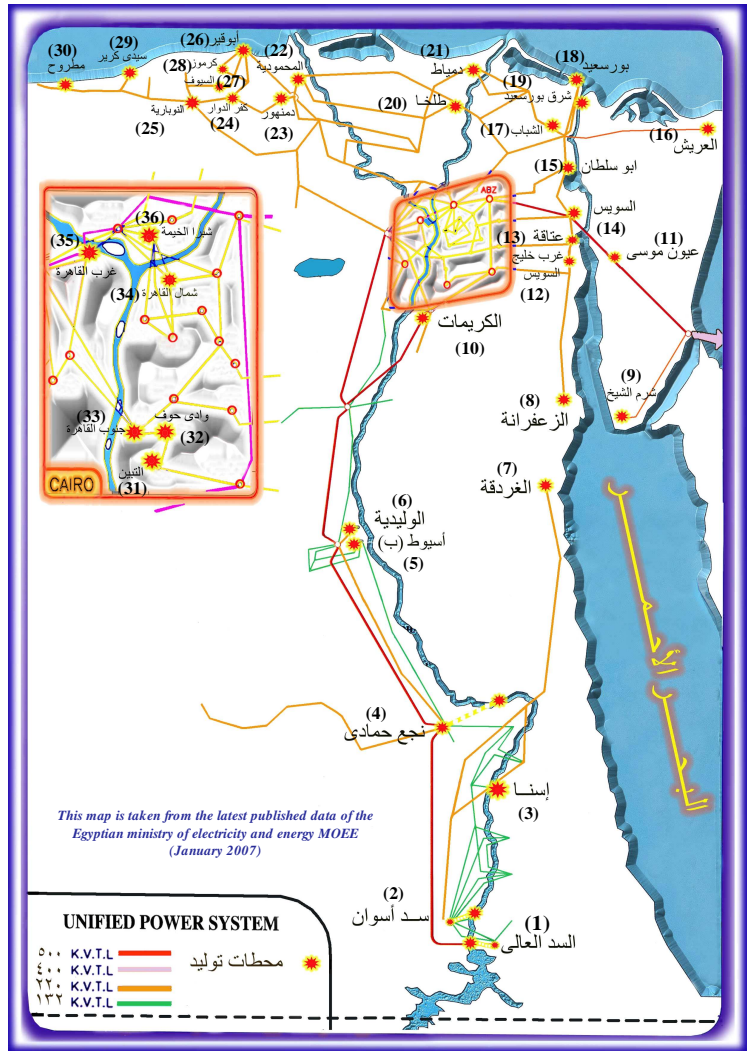

Figure 2: Electricity Map of the Egyptian UPS.

Table 2: Summary of the total unites and generated power of the Egyptian power stations

\begin{tabular}{|c|c|c|c|c|c|c|c|}
\hline & Power station & Type & \multicolumn{3}{|c|}{ Number of generating units } & \multicolumn{2}{|c|}{$\begin{array}{c}\text { Total generated power } \\
2004 / 2005\end{array}$} \\
\hline 1 & High Dam & Hydraulic & 12 units & 175 & MW each & 9049.000 & GWH \\
\hline 2 & Aswan (1 \&2) & Hydraulic & $\begin{array}{l}7 \text { units } \\
4 \text { units }\end{array}$ & $\begin{array}{l}40 \\
67.5\end{array}$ & $\begin{array}{l}\text { MW each, } \\
\text { MW each }\end{array}$ & 1663.474 & GWH \\
\hline 3 & Esna & Hydraulic & 6 units & 15 & MW each & 419.537 & GWH \\
\hline 4 & Naga-Hammady & Hydraulic & 3 units & 1.8 & MW each & 14.904 & GWH \\
\hline 5 & Assiut & Steam & 3 units & 30 & MW each. & 548.805 & GWH \\
\hline 6 & Al-Walidia & Steam & 2 units & 300 & MW each. & 2477.130 & GWH \\
\hline 7 & Hurghada & Gas & $\begin{array}{l}3 \text { units } \\
3 \text { units }\end{array}$ & $\begin{array}{l}23.5 \\
24.3 \\
\end{array}$ & $\begin{array}{l}\text { MW each, } \\
\text { MW each. }\end{array}$ & 49.799 & GWH \\
\hline 8 & Zafarana & Wind Farm & $\begin{array}{l}105 \text { units } \\
117 \text { units }\end{array}$ & $\begin{array}{l}0.6 \\
0.66\end{array}$ & $\begin{array}{l}\text { MW each, } \\
\text { MW each. }\end{array}$ & 512.300 & GWH \\
\hline 9 & $\begin{array}{l}\text { Sharm } \\
\text { Al-Sheikh }\end{array}$ & Gas & $\begin{array}{l}2 \text { units } \\
4 \text { units }\end{array}$ & $\begin{array}{l}23.7 \\
24.7 \\
\end{array}$ & $\begin{array}{l}\text { MW each, } \\
\text { MW each. }\end{array}$ & 84.011 & GWH \\
\hline 10 & Al-Kuraimat & Steam & 2 units & 627 & MW each. & 8077.201 & GWH \\
\hline 11 & Oion Mosa & Steam & 2 units & 320 & MW each. & 4318.907 & GWH \\
\hline 12 & $\begin{array}{l}\text { West } \\
\text { Suez-Gulf }\end{array}$ & Steam & 2 units & 341.25 & MW each. & 4427.000 & GWH \\
\hline 13 & Etaqa & Steam & $\begin{array}{l}2 \text { units } \\
2 \text { units }\end{array}$ & $\begin{array}{l}150 \\
300\end{array}$ & $\begin{array}{l}\text { MW each, } \\
\text { MW each. }\end{array}$ & 4138.514 & GWH \\
\hline 14 & Suez & Steam & $\begin{array}{l}4 \text { units } \\
1 \text { unit }\end{array}$ & $\begin{array}{l}22 \\
97\end{array}$ & $\begin{array}{l}\text { MW each, } \\
\text { MW. }\end{array}$ & 0000.000 & GWH \\
\hline
\end{tabular}




\begin{tabular}{|c|c|c|c|c|c|c|}
\hline & & Gas & 1 unit & 17 & MW. & Reconstruction state \\
\hline 15 & Abu Sultan & Steam & 4 units & 150 & MW each. & 3041.049 GWH \\
\hline 16 & El-Arish & Steam & 2 units & 33 & MW each. & 555.452 GWH \\
\hline 17 & Al-Shabab & Gas & 3 units & 33.3 & MW each. & $122.092 \mathrm{GWH}$ \\
\hline 18 & Port Said & Gas & $\begin{array}{l}1 \text { unit } \\
1 \text { unit } \\
1 \text { unit }\end{array}$ & $\begin{array}{l}20 \\
21 \\
23\end{array}$ & $\begin{array}{l}\text { MW, } \\
\text { MW, } \\
\text { MW. }\end{array}$ & $52.810 \quad$ GWH \\
\hline 19 & $\begin{array}{l}\text { Port Said } \\
\text { (East) }\end{array}$ & Steam & 2 units & 341.25 & MW each. & $4253.000 \quad \mathrm{GWH}$ \\
\hline 20 & Talkha & $\begin{array}{l}\text { Hybrid } \\
\text { Steam }\end{array}$ & $\begin{array}{l}8 \text { gas units } \\
2 \text { steam units } \\
2 \text { units }\end{array}$ & $\begin{array}{c}24.2 \\
45 \\
210\end{array}$ & $\begin{array}{l}\text { MW each, } \\
\text { MW each. } \\
\text { MW each. }\end{array}$ & $\begin{array}{cc}2677.880 & \text { GWH } \\
& \\
1827.941 & \text { GWH } \\
\end{array}$ \\
\hline 21 & Damieta & Hybrid & $\begin{array}{l}6 \text { gas units } \\
3 \text { steam units }\end{array}$ & $\begin{array}{l}125 \\
125 \\
\end{array}$ & $\begin{array}{l}\text { MW each, } \\
\text { MW each. }\end{array}$ & $7387.690 \quad$ GWH \\
\hline 22 & Al-Mahmoudia & $\begin{array}{l}\text { Hybrid } \\
\text { Gas }\end{array}$ & $\begin{array}{l}8 \text { gas units } \\
2 \text { steam units } \\
3 \text { units }\end{array}$ & $\begin{array}{l}24.5 \\
56 \\
45 \\
\end{array}$ & $\begin{array}{l}\text { MW each, } \\
\text { MW each. } \\
\text { MW each. }\end{array}$ & $\begin{array}{rr}2049.035 & \text { GWH } \\
75.908 & \text { GWH } \\
\end{array}$ \\
\hline 23 & Damanhour & $\begin{array}{l}\text { Hybrid } \\
\text { Steam old } \\
\text { Steam new }\end{array}$ & $\begin{array}{l}4 \text { gas units } \\
1 \text { steam units } \\
3 \text { units } \\
1 \text { unit } \\
\end{array}$ & $\begin{array}{c}24.2 \\
56 \\
65 \\
300 \\
\end{array}$ & $\begin{array}{l}\text { MW each, } \\
\text { MW. } \\
\text { MW each. } \\
\text { MW. }\end{array}$ & $\begin{array}{ll}1111.955 & \text { GWH } \\
1468.470 & \text { GWH } \\
1054.599 & \text { GWH }\end{array}$ \\
\hline 24 & Kafr El-Dawar & Steam & 4 units & 110.00 & MW each. & 1696.199 GWH \\
\hline 25 & Al-Nubaria & $\begin{array}{l}1^{\text {st }} \text { Hybrid } \\
2^{\text {nd }} \text { Hybrid }\end{array}$ & $\begin{array}{l}2 \text { gas units } \\
1 \text { steam unit } \\
2 \text { gas units } \\
1 \text { steam unit }\end{array}$ & $\begin{array}{l}250 \\
250 \\
250 \\
250 \\
\end{array}$ & $\begin{array}{l}\text { MW each, } \\
\text { MW. } \\
\text { MW each, } \\
\text { MW. }\end{array}$ & $134.000 \quad \mathrm{GWH}$ \\
\hline 26 & Abu-Qir & $\begin{array}{l}1^{\text {st }} \text { Steam } \\
2^{\text {nd }} \text { Steam }\end{array}$ & $\begin{array}{l}4 \text { steam units } \\
1 \text { steam units }\end{array}$ & $\begin{array}{l}150 \\
300 \\
\end{array}$ & $\begin{array}{l}\text { MW each. } \\
\text { MW. }\end{array}$ & $4871.700 \mathrm{GWH}$ \\
\hline 27 & Al-Siouf & $\begin{array}{l}\text { Steam } \\
\text { Gas }\end{array}$ & $\begin{array}{l}2 \text { steam units } \\
2 \text { steam units } \\
6 \text { gas units }\end{array}$ & $\begin{array}{l}26.5 \\
30 \\
33.3 \\
\end{array}$ & $\begin{array}{l}\text { MW each, } \\
\text { MW each. } \\
\text { MW each. }\end{array}$ & $\begin{array}{rr}97.163 & \text { GWH } \\
409.25 & \text { GWH } \\
\end{array}$ \\
\hline 28 & Karmouz & Gas & 2 units & 12.5 & MW each. & 4.304 GWH \\
\hline 29 & Sidi-Krier & $\begin{array}{l}\text { Steam }(1,2) \\
\text { Steam }(3,4)\end{array}$ & $\begin{array}{l}2 \text { steam units } \\
2 \text { steam units }\end{array}$ & $\begin{array}{c}320 \\
341.25\end{array}$ & $\begin{array}{l}\text { MW each. } \\
\text { MW each. }\end{array}$ & $\begin{array}{c}3974.352 \text { GWH } \\
\text { Reconstruction state(Until } \\
\text { 2027) } \\
\end{array}$ \\
\hline 30 & Matrouh & Steam & 2 units & 30.0 & MW each. & 324.248 GWH \\
\hline 31 & Al-Tibin & $\begin{array}{l}\text { Steam } \\
\text { Gas } \\
\end{array}$ & $\begin{array}{l}3 \text { steam units } \\
2 \text { gas units }\end{array}$ & $\begin{array}{l}15 \\
23 .\end{array}$ & $\begin{array}{l}\text { MW each. } \\
\text { MW each. }\end{array}$ & $\begin{array}{cc}202.139 & \text { GWH } \\
\text { Scrap since } & 8 / 6 / 2005 \\
36.838 & \text { GWH } \\
\end{array}$ \\
\hline 32 & Wadi-Hof & Gas & 3 units & 33.3 & MW each. & $63.876 \mathrm{GWH}$ \\
\hline 33 & Cairo (South) & $\begin{array}{l}1^{\text {st }} \text { Hybrid } \\
2^{\text {nd }} \text { Hybrid }\end{array}$ & $\begin{array}{l}3 \text { gas units } \\
3 \text { steam unit } \\
1 \text { gas units } \\
1 \text { steam unit }\end{array}$ & $\begin{array}{r}110 \\
60 \\
110 \\
55\end{array}$ & $\begin{array}{l}\text { MW each, } \\
\text { MW each. } \\
\text { MW, } \\
\text { MW. }\end{array}$ & $\begin{array}{rr}3619.000 & \mathrm{GWH} \\
903.560 & \mathrm{GWH}\end{array}$ \\
\hline 34 & Cairo (North) & $\begin{array}{l}1^{\text {st }} \text { Hybrid } \\
2^{\text {nd }} \text { Hybrid }\end{array}$ & $\begin{array}{l}2 \text { gas units } \\
1 \text { steam unit } \\
2 \text { gas units } \\
1 \text { steam unit }\end{array}$ & $\begin{array}{l}250 \\
250 \\
250 \\
250 \\
\end{array}$ & $\begin{array}{l}\text { MW each, } \\
\text { MW each. } \\
\text { MW each, } \\
\text { MW. }\end{array}$ & $\begin{array}{l}2635.390 \mathrm{GWH} \\
\text { Under construction }\end{array}$ \\
\hline 35 & Cairo (West) & $\begin{array}{l}\text { Steam old } \\
\text { Steam new }\end{array}$ & $\begin{array}{l}4 \text { steam unit } \\
2 \text { steam unit }\end{array}$ & $\begin{array}{l}87.5 \\
330 \\
\end{array}$ & $\begin{array}{l}\text { MW each. } \\
\text { MW. }\end{array}$ & $\begin{array}{ll}1962.770 & \text { GWH } \\
3892.994 & \text { GWH } \\
\end{array}$ \\
\hline 36 & $\begin{array}{l}\text { Shubra } \\
\text { El-Khaima }\end{array}$ & Steam & 4 units & 315 & MW each. & $8609.577 \quad$ GWH \\
\hline
\end{tabular}




\section{The Open Source Simulation Tool}

Many powerful software packages are available for analyses of power system stability. Some of them are fully developed commercial tools, while others are open source programs. PSAT, a freely distributed Matlab-based power system analysis program developed by Dr. Federico Milano [8-10], stands out among those open source programs for its relatively complete functionality. It includes principal code routines for power flow, continuation power flow, optimal power flow, small-signal stability analysis, and time-domain simulation. The core of PSAT is the power flow routine, which also takes care of state variable initialization. Once the power flow has been solved, further static and/or dynamic analysis can be performed through the following additional routines:

1. Continuation power flow (Bifurcation Analysis);

2. Optimal power flow;

3. Small signal stability analysis;

4. Time domain simulations;

5. Phasor measurement unit (PMU) placement.

To fulfil these analyses, PSAT supports a variety of static and dynamic models. For example, in a static analysis, a synchronous generator can be modeled as a slack bus or a PV bus; however, in a dynamic analysis, options of the synchronous generator model with a dynamic order varying from 2 to 8 are provided. However, PSAT supports several static and dynamic models, including non-conventional loads, induction machines, regulators, and FACTS. PSAT is also provided with a complete set of userfriendly graphical interfaces and a Simulink-based editor of one-line network diagrams [8-10]. Basic features, algorithms, and a variety of case studies have been presented previously by the author [11, 12]. This has illustrated the capabilities of PSAT and its suitability for educational as well as research purposes. These characteristics make PSAT attractive to be selected for the work presented in this paper. During the research, all concerned PSAT codes have been carefully investigated. Some small errors have been fixed and some models have been developed to adapt the proposed UPS model in this paper.

\section{The Simulated UPS Model}

Table 2 has a summary of the total unites and the corresponding generated power of the Egyptian UPS. In this paper a considerable portion of UPS will be modeled for simulation with PSAT (The marked stations of table 2). This portion constitutes all the power systems that exist in Cairo, Upper
Egypt beside some stations in Suez and the Zafarana wind farm. The proposed sample model for UPS simulation includes the most strategic 12 stations which includes more than 46 synchronous generators plus the 122 units that figure the wind farm. It is important to state the power system under consideration is a heavily loaded power system as it contains the most important industrial loads such as Naga-Hammady Aluminum factory, Ferrosilicon, Kima, and cement factories in addition to the heaviest domestic load of Cairo.. This sample model is illustrated in figure 3 which also contain the power transformers, and the different high voltage transmissions circuits with all the machine, transformer, and load buses. Models and data for the steam, gas, and hydraulic power stations are taken as explained in the previous section, while those for the wind farm are taken from references [13-16]. However PSAT is advantageous in this concern since it provides the base model for wind turbines which can be modified to represent the 122 units of Zafarana. Depending on the degree of the 46 synchronous machines models, one can get an overall order not less than 731 state variables. It is not an easy task to represent such a model and it has been proved that some packages may fail to simulate it.

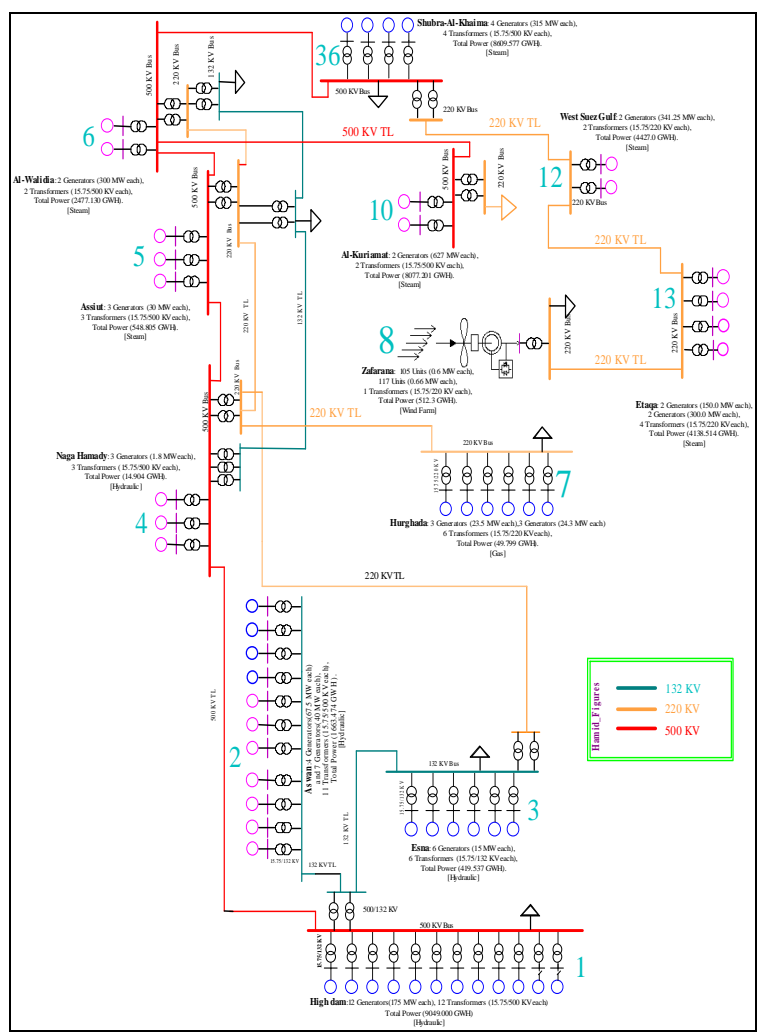

Figure3: The simulated UPS sample model. 


\section{Simulation Results}

The most tedious effort in this paper concerns the building step of the UPS model in the open source environment. First the all the components of the UPS topology should be drawn in the PSAT environment corresponding to the electricity map of Fig. 2. Then the data should be exactly typed in tens of dialogue boxes related to every component. Finally, the overall system should be exposed to a test run for steady state (without any type of faults). If the system topology has been built correctly with exact data, the steady state simulation will assure such step with constant values for all the system states (e.g. all omegas should be steady at the "one" per unit value). If not, one should review all the typed data and correct the errors. The next step is to test the UPS in case of fault. The fault location should be selected in a bus with the most connection. In this paper the system is exposed to three phase fault at Shubra El- Khaima power station for 6 cycles period. This fault has influenced the overall UPS states. For example Fig. 4 shows the speed oscillations for 5 generators at 5 different stations. It is clear that the fault influence the speed oscillations with different degrees. Some generators may have light fluctuations while others may have undecayed oscillations. In this paper it is not intended to analyse the simulation results, since the results are expected and coincide with the logic in this aspect. It is just intended to model the overall UPS and to apply the new package to ensure that the model is correctly formulated. Results of Fig. 3 have proved that the model is correct, and this represents an essential goal of this paper.

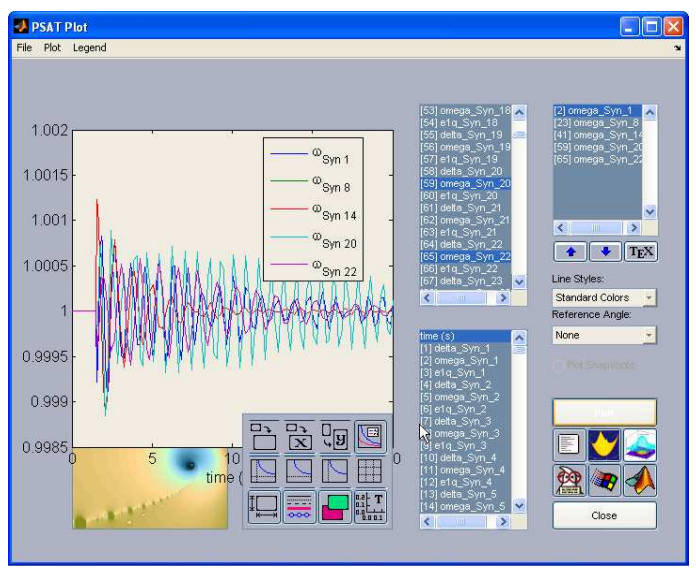

Figure 4: Simulation results of some UPS generators located at different stations.

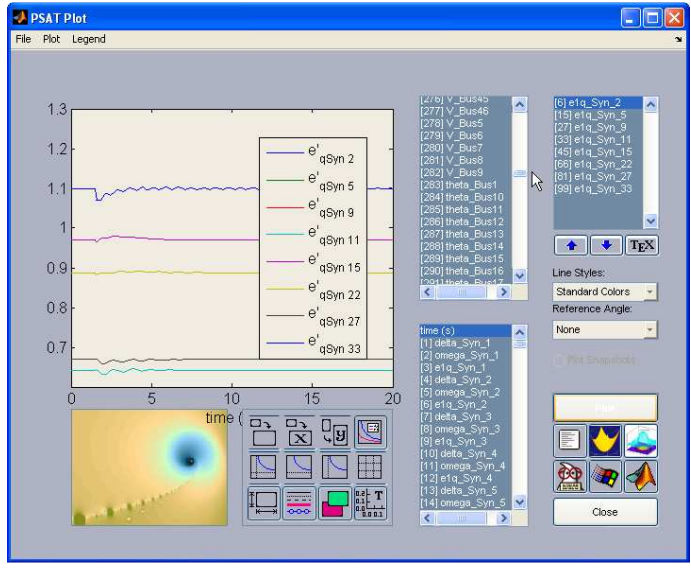

Figure 5: Simulation results of some generator

$$
\text { e.m.f's. }\left(e^{\prime}{ }_{q}\right) \text {. }
$$

Figure 5 show the e.m.f. results of some generators, also, at different power plants. The results also start from pre-fault steady state values, then the generators e.m.f's will fluctuate as a response to the fault. However, figures 6,7 show the active and reactive power oscillations at different buses. It is obvious that the active and reactive power oscillations will be worst at the faulty bus (Bus 1), while the oscillations may be minimal at rear buses such as bus 46 which corresponds to the Etaqa power plant. These results coincide with the practical experience of UPS. The Author of this paper has proved in a previous publication [17] that the Shubra El-Khaima region is one of the most dominant UPS sectors which have experienced SSR-like failure two times around the middle of the previous decade especially in the region containing the system shown in Fig.8.

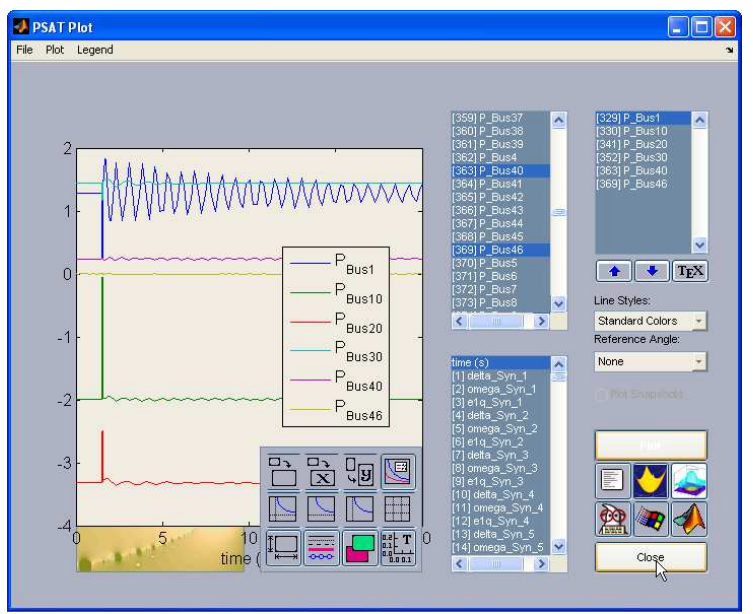

Figure 6: Active power response at different buses 


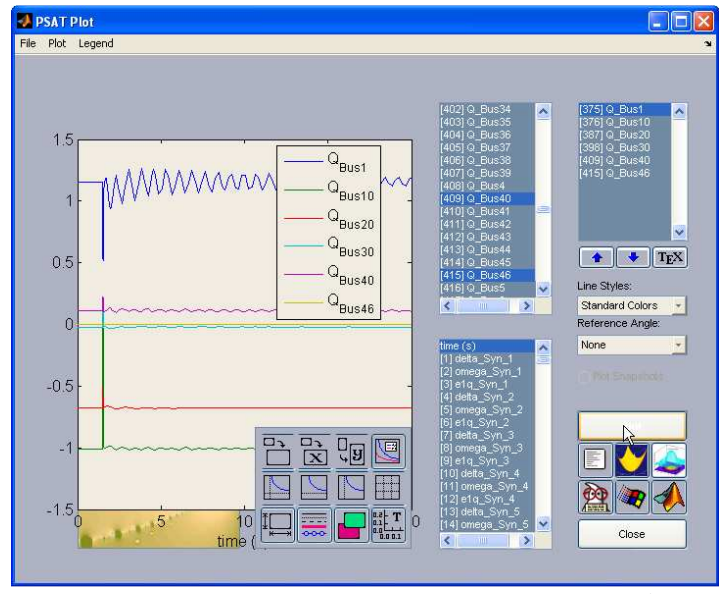

Figure 7: Rreactive power response at same buses

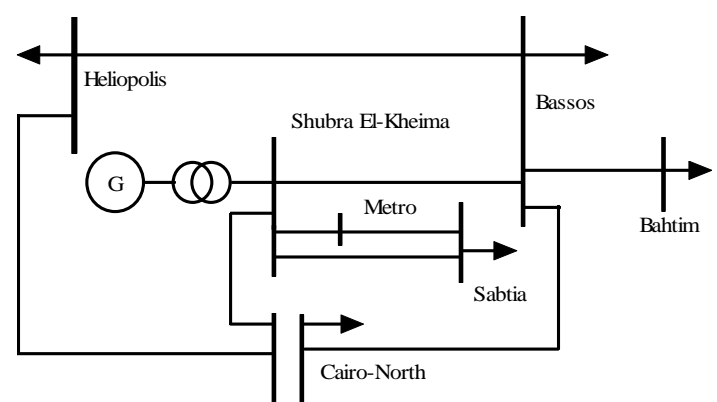

Figure 8: A UPS sector that experienced two SSRlike failures in 1992.

An interesting novel point in this simulation is the division regarding the wind power farm of $\mathrm{Al}$ Zafarana. For the first time, this paper presents modeling and simulation of this division as a part of the overall UPS. In PSAT, three categories of wind turbines are included: constant speed wind turbine with squirrel cage induction generator, variable speed wind turbine with doubly fed (wound rotor) induction generator and variable speed wind turbine with direct drive synchronous generator.

Details of the models are omitted for the sake of paper reduction. However, in this paper the 220 wind units of Al-Zafarana have been modeled with the second category which is illustrated in Fig. 9. Also this coincides with the technical data of AlZafarana projects. Among the plenty of results in this context, only a Comparison between speed variations of synchronous generators (Here one of the West Suez-Gulf generators ) and one of the wind turbine with doubly fed induction generator of Al-Zafarana for the same fault is shown in Fig. 10.

\section{Conclusions:}

The paper has presented a trial to formulate a model for the whole Egyptian power system network. The model is based on the latest published data which has been reported for the UPS.

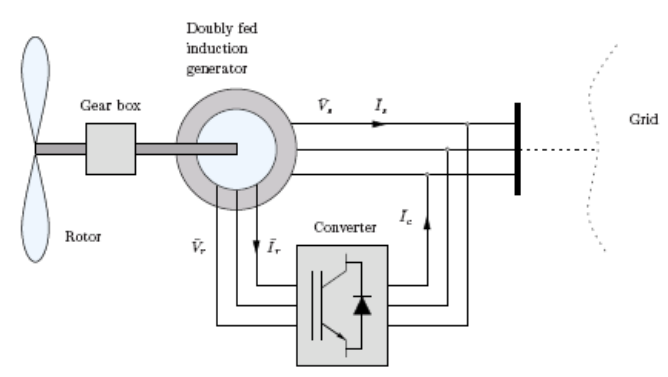

Figure 9: Al-Zafarana wind farm modeled as variable speed wind turbine with doubly fed (wound rotor) induction generator

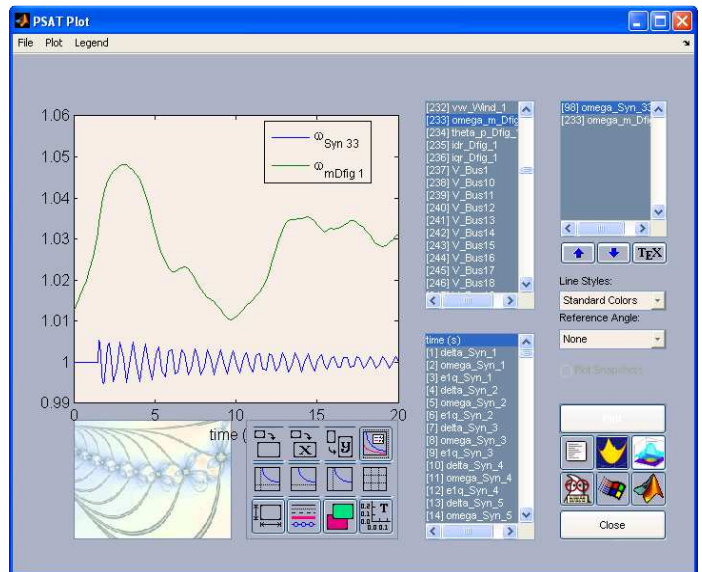

Figure 10: Comparison between speed variations of a synchronous generator (Here one of the West Suez-Gulf generators $\omega_{\text {syn } 33}$ ) and one of the wind turbine with doubly fed induction generator $\omega_{D f i g}$ of Al-Zafarana for the same fault.

The model includes all the different power system technologies such as hydraulic, steam, gas, solar as well as wind farm plants. In the next part of this paper the presented model has been simulated with one of the most recent computer packages. A very recent open source code package has been selected for such simulation since it is free and user friendly. This package has proved its convenience to be applied for very complicated large scale systems with minimum effort. For example if we take only those significant portions of the Egyptian grid, we'll get 731 states (57 buses and 46 synchronous machines in addition to the induction generators of the wind farm) to be simulated and monitored. This PSAT Package has been applied for such complicated system without any failure or instability in simulation. Moreover, it has been found that PSAT application reduces a lot of time in setting up the power system topology and in 
preparing several additional files for the same case study if it is dealt with other packages. Simulation results obtained in this paper coincide with the published results that have been reported by EEHC.

\section{Acknowledgement}

The authors deeply appreciate the Egyptian Ministry of Electricity and Energy (EMEE) for providing all the necessary information required to accomplish this research work.

\section{References}

[1] Arab republic of Egypt, Ministry of Electricity and Energy, Egyptian Electricity Holding Company, "Annual Report 2003-2004", English Version, 2004.

[2] Arab republic of Egypt, Ministry of Electricity and Energy, Egyptian Electricity Holding Company, "Annual Report 2004-2005", English Version, 2005.

[3] Arab republic of Egypt, Ministry of Electricity and Energy, Egyptian Electricity Holding Company, "Annual Report 2005-2006", Arabic Version, 2006.

[4] The official website of the ministry of Electricity and Energy, www.moee.gov.eg.

[5] P. M. Anderson., A.A. Fouad ., "Power System Control and Stability", $1^{\text {st }}$ ed., Vol.1, Iowa state univ. press, 1977.

[6] IEEE Power Engineering Society, IEEE-SA Standards Board, „IEEE Guide for Synchronous Generator Modeling Practices and Applications in Power System Stability Analyses“, IEEE Std 1110 ${ }^{\mathrm{T}}$ 2002.

[7] El Sayed Tag Eldin, Hany Elghazaly, and Mohamed Moussa., " An Integrated Protective Scheme for a multi- ended Egyptian Transmission Line using Radial Basis", The International Conference on Power Systems Transients (IPST'05), Montreal, Canada, June 19-23, 2005.

[8] Federico Milano, PSAT, "Power System Analysis Toolbox", Documentation for PSAT version 1.3.4, July, 14, 2005.

[9] Federico Milano, PSAT, "Power System Analysis Toolbox", Documentation for PSAT version 2.0.0 $\beta 1$, December 14, 2006
[10] Federico Milano, PSAT, "Power System Analysis Toolbox", Documentation for PSAT version 2.0.0 $\beta 2$, March 8, 2007

[11] A. M. Abdel-Hamid: "The Rule And Benefits Of The Most Recent Computation Packages To Investigate Highly-Sophisticated Electric Power Systems: Part I: PSAT application for modeling, simulation, and control of multi-area dissimilar power system", a paper submitted and accepted to be published by the International Conference on Electrical Engineering Design and Technologies (ICEEDT) , Hammamet, Tunisia, November 5-6, 2007.

[12] A. M. Abdel-Hamid: "The Rule And Benefits Of The Most Recent Computation Packages To Investigate Highly-Sophisticated Electric Power Systems: Part II: Reference Benchmarks for Modeling, Simulation and Control of Synchronous Machines with PSAT", a paper submitted and accepted to be published by the International Conference on Electrical Engineering Design and Technologies (ICEEDT) , Hammamet, Tunisia, November 5-6, 2007.

[13] A. M. Tawfic, "Baseline For Japanese Wind Power Plant in Zafarana Project (Arab Republic of Egypt)", National Renewable Energy Agency (NREA), 2000 http://cdm.unfcc.int/methodologies/process

[14] Ashour Abdel Salam Moussa, "Wind Energy in Egypt", DEWI Magazine Nr. 17, August 2000.

[15] Bothayna Rashed, "WIND ENERGY IN EGYPT”, ESI AFRICA ISSUE 3, 2006.

[16] Lahmeyer International Group, "Wind Parks in the Desert", Information On The Lahmeyer International Group, No. 50 / August 2005.

[17] A. S. Abdel-Ghaffar, A. H. Morsi, A. M. Abdel-Hamid and M. A. Elmashad:“A Novel SSR- Countermeasure Through Appropriate Design Of The Shaft-Dynamic Parameters", Engineering Research Bulletin, Faculty Of Engineering, Minufiya University, Shebin ElKom, Egypt. Vol. 23, No.3,2000, ISSN 11101180, Pp. 147-162, June,6th 2000. 